\title{
PARTICULATE AMMONIA IN SEA WATER
}

\author{
By L. H. N. Cooper, D.Sc., F.R.I.C.
}

Chemist at the Plymouth Laboratory

In the English Channel during the winter months vertical mixing is thorough, so that in 50-100 m. of water temperature and salinity are usually uniform from surface to bottom. Other truly dissolved substances would also be expected to be uniformly distributed. The erratic distribution of iron has been shown to arise from its particulate nature, whilst small vertical variations of inorganic phosphate in winter as well as occasional poor agreement between replicate phosphate analyses are most probably due to particulate ferric phosphate (Cooper, 1948).

Two features of the ammonia analyses made in 1930-3I have always caused the writer concern. That ammonia, with its ready solubility and inability to form insoluble compounds, must be in true solution seems axiomatic. Yet, on the three cruises to International Hydrographic Station E I (72 m. depth) on 4 December 1930, I3 January and 4 February I93I, there were marked maxima of ammonia at surface and bottom (Cooper, 1933, fig. 6). Rapid though regeneration of ammonia from decaying material may have been, it is odd that vertical mixing could have allowed dissolved ammonia so to accumulate. Surface samples were taken with a wooden bucket and so included a portion of the surface film.

Wattenberg's absorptiometric method (1928), which was then used, is not highly accurate within the range of concentrations studied. It was difficult completely to ensure that the prepared sea water used for making standards was ammonia-free. Though absolute accuracy may have been none too good, the relative precision of measurement between duplicates compared at the same time not only with standards but with one another was much better. Frequently the difference between duplicates or triplicates amounted to $0.7 \mathrm{mg}$.-atom $/ \mathrm{m}$. $^{3}$ or more. Notebook comments such as 'results ignored; high figures attributable to contamination' were frequent. Such an analytical distribution is very reminiscent of that for iron.

Again, Redfield \& Keys (1938) made a series of most careful analyses in the Gulf of Maine by the vacuum distillation technique of Krogh (1934). They remark that 'to be reliable, all determinations must be made in duplicate, since unforeseen contamination frequently occurred'. In other words, duplicates did not agree. Further (p. 87), they say: 'The distribution of ammonia appeared very irregular when the observations were first made.... It appeared, however, that great differences might be observed in similar situations at any time and in the same situation at different times.' 
One is entitled to question whether these erratic results were really due to analytical error or contamination.

In April and May I936 in Japanese coastal waters very many analyses were made by the research vessel Syunpu Maru (1938). The text is in Japanese, but the table of results has English headings. The distribution of temperature, salinity, density, oxygen, $\mathrm{pH}$, silicate, phosphate, nitrite and nitrate agree with what might be expected of dissolved substances in shallow, partially stratified, temperate waters in spring. On any accepted view of the distribution of dissolved substances, the many results for iron and ammonia are chaotic even at stations which were isothermal and isohaline. The iron results now fall into line with the picture of particulate iron drawn for the English Channel. Is it reasonable to ascribe the Japanese results for ammonia also to a particulate distribution?

In spite of determined efforts by a large number of workers, no nitrifiers able to oxidize ammonia to nitrite have ever been found in sea water as such. These attempts are listed by Carey (I938) and ZoBell (I946, pp. I5I-53). Nitrifying organisms have, however, been found associated with bottom deposits and with animal and plant plankton collected near shore in relatively shallow places (Waksman, Reuszer, Carey, Hotchkiss \& Renn, I933; Carey, I938).

When Harvey (I940) presented diatom cultures with mixtures of ammoniumand nitrate- $N$, analysis showed that, in the light, ammonium- $N$ was preferentially removed whereas in the dark the content of ammonium- $N$ in the culture as found by analysis remained unchanged. Nevertheless, the dark experiments were compatible with some of the ammonium- $N$ having been adsorbed by the cells whilst remaining accessible to bulk analysis of the water including everything in it.

A possible key to the riddle is provided by the work of Lees \& Quastel (I946) on soil nitrification of ammonia. They concluded that soil ammonia is held on the surfaces of the soil crumbs by base-exchange combination and that the nitrifying bacteria proliferate only at the expense of such adsorbed ammonium cations. Some such adsorption of part of the ammonia in sea water upon particulate matter would provide an explanation of the experimental findings more reasonable than the exasperatingly frequent 'contamination'. Undissociated ammonia $\left(\mathrm{NH}_{3}\right)$ and ammonium-ion $\left(\mathrm{NH}_{4}{ }^{+}\right)$are present in sea water in not dissimilar amounts (Cooper, I937) so that adsorption of either might occur.

All these observations may be brought within the following working hypothesis. In the sea ammonia is formed by the breakdown of amino- and amido- $N$ in decaying matter, most of which is particulate. It may not be immediately given up to the water but may be retained on the surfaces of the particles as adsorbed ammonia $\left(\mathrm{NH}_{3}\right)$, ammonium-ion $\left(\mathrm{NH}_{4}{ }^{+}\right)$or conceivably as a weak, readily hydrolysable amido-grouping (-CO. $\mathrm{NH}_{2}$ ). Such particles 
with densities slightly different from that of the water will accumulate in the surface or bottom strata of the water mass or may be entrained by interfacial tension in the sea surface itself. None the less, their adsorbed ammonia would be determinable by any of the methods of analysis for dissolved ammonia. On such particles-perhaps nowhere else-nitrifying bacteria may find not only a structure on which physically to support themselves as seems necessary in soils but also the ammonium substrate they need. Success in culturing nitrifying bacteria would therefore demand a particulate rather than a plate technique. Ammonia added in solution to phytoplankton cultures would tend of itself to become adsorbed upon the plants in a way which would only be revealed if the plants were removed before analysis. Such capacity of ammonia- $N$ for preferential adsorbtion would make it a more favourable plant food than nitrite or nitrate.

If the possibility of removal of ammonia from the aqueous phase of sea water by adsorption upon particles be admitted, 'contamination' as an explanation of the failure of replicate analyses to agree is no longer necessary. Occasionally it must occur, but more often results would be due to random distribution of 'particulate ammonia' of the type now known to apply to iron.

Though this hypothesis gives a coherent explanation of a number of observations, previously somewhat intractable, it is none the less highly speculative. It is put forward here since an opportunity for the writer to test it for himself is unlikely to arise in the near future.

\section{SUMMARY}

The hypothesis is proposed that inorganic ammonia may be adsorbed on particulate matter in the sea. The random distribution of such particulate ammonia would account for the frequent ' contamination' reported in ammonia analyses and for the finding of nitrifying bacteria associated only with particulate matter, but never with sea water itself.

\section{ADDENDUM}

The Editor has shown me the proofs of a contribution to this Volume (pp. 360-79) by S. M. Marshall \& A. P. Orr (I948) on the effect of different plant nutrients upon the phytoplankton in Loch Craiglin. In certain experiments added nutrients disappeared from the water of this shallow loch very rapidly indeed. This suggested to the authors either that the nutrients were speedily absorbed by the phytoplankton and fixed algae, or that they were adsorbed by mud or suspended dead particulate matter. For salts of ammonia, notably the experiments of 2 April I 945 and Io January I946, the second view accords with the hypothesis here presented. Dr Orr (in litt.) states that Dr Steemann Nielsen in informal discussion has expressed the same idea to Dr Marshall. The uncertainty inherent in analytical data for nitrate allow of no conclusion 
at present as to possible particulate distribution of adsorbed nitrate in the sea. Such a distribution must be considered unlikely until positive evidence can be produced in its favour. There is nothing in the known distribution of phosphate in the open sea to lend support to a particulate hypothesis for this nutrient on the scale required by the Loch Craiglin results. None the less it would be of interest to know whether the moorland stream or burn brings any considerable amount of iron into Loch Craiglin and, if so, whether ferric phosphate might be formed and precipitated. The $\mathrm{pH}$ of Loch Craiglin varied widely during the investigation and, as will be seen from a companion paper to this, ferric phosphate is more likely to be formed when $\mathrm{pH}$ is low.

\section{REFERENCES}

CAREY, C. L., I938. The occurrence and distribution of nitrifying bacteria in the sea. fourn. Mar. Res., Vol. I, pp. 29I-304.

Cooper, L. H. N., 1933. Chemical constituents of biological importance in the English Channel, November I930 to January 1932. Part I. Phosphate, silicate, nitrate, nitrite, ammonia. Fourn. Mar. Biol. Assoc., Vol. 18, pp. 677-728.

- I937. The nitrogen cycle in the sea. Fourn. Mar. Biol. Assoc., Vol. 22, pp. 183-204. I948. The distribution of iron in the waters of the western English Channel. fourn. Mar. Biol. Assoc., Vol. 27, pp. 279-3r3.

Harvey, H. W., I940. Nitrogen and phosphorus required for the growth of phytoplankton. Fourn. Mar. Biol. Assoc., Vol. 24, pp. II 5-23.

KROGH, A., I934. A method for the determination of ammonia in water and air. Biol. Bull. Woods Hole, Vol. 67, pp. I26-31.

LeEs, H. \& QuAstel, J. H. I946. Biochemistry of nitrification in soil. The site of soil nitrification. Biochem. Fourn., Vol. 40, pp. 815-23.

Marshall, S. M. \& ORR, A. P., I948. Further experiments on the fertilization of a sea loch (Loch Craiglin). The effect of different plant nutrients on the phytoplankton. Fourn. Mar. Biol. Assoc., Vol. 27, pp. 360-79.

Redfield, A. C. \& KeYs, A. B., I938. The distribution of ammonia in the waters of the Gulf of Maine. Biol. Bull., Vol. 74, pp. 83-92.

Syunpu Maru, 1938. The results of the oceanographical observations on board the R.M.S. Syunpū Maru in the Ariake and Yatusiro-Kai (April-May, 1936). (In Japanese.) Fournal of Oceanography, Vol. xI, No. 3, pp. 545-53.

Waksman, S. A., Reuszer, H. W., Carey, C. L., Hotchkiss, M. \& RenN, C. E., I933. Studies on the biology and chemistry of the Gulf of Maine. III. Bacteriological investigations of the sea water and marine bottoms. Biol. Bull. Woods Hole, Vol. 64, pp. 183-205.

WATTENBERG, H., I928. A simple method for the direct estimation of ammonia in sea water by the use of Nessler's reagent. Conseil int. p. l'Exploration de la Mer. Rapp. et Proc.-verb., Vol. 53, pp. 108-I4.

ZoBell, C. E., I946. Marine Microbiology. Waltham, Mass., U.S.A., Chronica Botanica Company, pp. I-240. 